\title{
Biosensors Used for Quantification of Nitrates in Plants
}

\author{
Romero-Galindo Raul, Torres-Pacheco Irineo, Guevara-Gonzalez Ramon Gerardo, \\ and Contreras-Medina Luis Miguel
}

CA Ingeniería de Biosistemas (Biosystems Engineering Group), División de Estudios de Posgrado, Facultad de Ingeniería, Universidad Autónoma de Querétaro, Cerro de las Campanas, S/N, 76010 Santiago de Queretaro, QRO, Mexico Correspondence should be addressed to Guevara-Gonzalez Ramon Gerardo; ramonggg66@gmail.com and
Contreras-Medina Luis Miguel; mcontreras.uaq@gmail.com

Received 8 October 2015; Revised 21 December 2015; Accepted 22 December 2015

Academic Editor: Chenzhong Li

Copyright (C) 2016 Romero-Galindo Raul et al. This is an open access article distributed under the Creative Commons Attribution License, which permits unrestricted use, distribution, and reproduction in any medium, provided the original work is properly cited.

\begin{abstract}
Nitrogen is essential for the plant because it is used for the production of chlorophyll, proteins, nucleic acids, amino acids, and other cellular compounds; nitrogen is available in two forms: ammonium and nitrate. Several tools have been used to quantify nitrates in plants such as the Kjeldahl method and Dumas combustion digestion; however, they are destructive and long time-consuming methods. To solve these disadvantages, methods such as selective electrodes, optical sensors, reflectometers, and images based sensors have been developed; nonetheless, all these techniques show interference when carrying out measurements. Currently, biosensors based on genetic constructions, based on the response of promoter gene fused to Gene Fluorescent Protein (GFP), are gaining popularity, because they improve the accuracy of measurements of nitrate by avoiding the interference of carriers ion, high salt conditions, and other factors. The present review shows the different methods to quantify the nitrogen in plants; later, a biosensors perspective is presented, mainly focused on biosensors based on organism genetically modified. The review presents a list of promoter and reporter genes that could be used to develop different kind of sensors, and a perspective of sensors to measure quantitatively the nitrogen is presented.
\end{abstract}

\section{Introduction}

Nitrogen is the most important nutrient in plants because it is required for chlorophyll production and other cellular compounds (proteins, nucleic acids, and amino acids) [1]. The nitrogen is disposable in two forms that are ready to be used by the plants: ammonium $\left(\mathrm{NH}_{4}{ }^{+}\right)$and nitrates $\left(\mathrm{NO}_{3}{ }^{-}\right)$[2] Nitrate is absorbed in more quantities than ammonium [3]; however, if this absorbance is not balanced, in agreement to the requirements of the crop, it becomes in a factor that limits the normal growth of the plants [4] affecting drastically the crops production, mainly by the deficiency or toxicity of the nitrates [5].

The aforementioned reasons give the necessity of accomplishing a diagnostic of the nutrimental estate of the plants in a rapid, reliable, and precise way, in order to help the correct application of this nutrient. To achieve this, several tools and methodologies have been used [6]. However, the methods commonly employed, such as Kjeldahl Digestion and Dumas combustion, are destructives and take long time for the analysis [7]. To avoid these disadvantages, rapid methods have been developed to determine the quantity of $\mathrm{NO}_{3}{ }^{-}$; one of them is through nitrate-selective electrodes; however, this has presented interferences caused by the presence of other acceptor ions [8].

There are other methods based on optics principles to measure nitrates like radiometers, reflectometers, and sensors based on satellite images (dozel reflectance), leaf transmittance, and chlorophyll and fluorescence polyphenols [9]. These methods have high correlations between the optical parameters and nitrogen content of the plants and have the advantage of being nondestructive [7]; however, there are some drawbacks such as chlorophyll saturation, atmospheric interferences, and the high cost of the instruments.

Other technologies that could help to avoid the interferences presented by the optical sensors are the biosensors [10], principally those based on genetic constructions where a promoter sensitive to nitrate is fused to a Green Fluorescent 
Protein (GFP) to measure, quantitatively, nitrates. This kind of sensors allows improving the precision of the measurements because there are no interferences produced by ions and external factors that could alter the estimations [10]; however, there are several factors that affect the fluorescence of the Green Fluorescent Protein (GFP), such as the presence of imidazole and high salinity [11]; nonetheless, the GFP does not have affinity with divalent cation, which is an advantage, unlike the other conventional methods used for quantifying nitrates [12]. The GFP is not an enzyme and results in being an excellent indicator because it does not interfere with the physiological mechanism of the cell [12]. The interval of $\mathrm{PH}$ of purification process is maintained generally between 7 and 8 as optimal for GFP [11].

The responses to this kind of biosensors are being employed due to its sensibility and versatility [13], being the sensitivity of the fluorescence proportional to the concentration of extracellular nitrate [10]; however, biosensors using GFP take long time to be prepared; developing this kind of devices takes a long time; so far, there are no suitable electronic devices for this task to be applied in crops.

\section{Methods to Measure Nitrates}

Several tools can be applied to measure nitrates in plants [6] and they have been reported to be suitable for achieving rapid analysis in plants with the goal of helping in the management of nitrates. Several methods for nitrogen quantification are presented.

2.1. Selective Electrodes of Ion-Nitrates. There are nitrateselective electrodes in the market that are designed for being used in agriculture, allowing easy and fast measurements due to their portability. These characteristics allow this kind of devices to accomplish better nutritional programs. One of the most used sensors is the ion-selective electrode. These electrodes are based on ionophores, which are made by chemical compounds that are joined, selectively, to other ions of interest; these kinds of electrodes have been used for the analysis in situ due to their high selectivity. The sensors here presented requirement of an internal reference electrode and a solution, being the last drawback because it makes the maintenance of the device difficult [14]. Another problem presented in this kind of electrodes is the error that occurred when they are tested in high salinity solutions. Due to the presence of interference ions, such as chloride, the results could indicate the existence of these compounds, obtaining higher values compared with other methods [15]. The errors carried out by the high salinity solutions can be solved by adding silver sulphate; however, it results in being expensive. The most problematic situations are the high concentrations of chloride, bromide, and other compounds; when there are suspicions of having interferences, it is necessary to test the results in a reference laboratory. Calibration of the sensors could lead to better measurements [16].

Brambilla et al. [15] carried out a study about the validation (following the validation guide of assay methods of the 9 OAA (2008) and the guide EURACHEM (1998)) using three distinct methods for determining the quantity of nitrates: ion-selective electrodes, nitracheck, and chromotropic acid were used to evaluate the parameters of veracity, precision, and uncertainty using several reference samples. The chromotropic methods result in being suitable for $\mathrm{NO}_{3}$ analysis, because values of veracity were reached (veracity $<10 \%$ without significant references). Besides, the selective ion electrode method did not accomplish satisfactory results, because the required values of veracity and uncertainty were not reached; the reason of this was the high concentration of $\mathrm{NO}_{3}$ that could be associated with high salinity content of the soil. The nitracheck method is not applicable for the determination of $\mathrm{NO}_{3}$ due to its high limit of quantification, even though it have reached the veracity values (veracity < $10 \%)$.

2.2. Nitrate Strips. The strips of nitrate contain two reactive zones that change its color when they are exposed to a nitrate solution. The ions are reduced to nitrite: the nitrate ions are reduced to nitrites: the nitrite reacts with an aromatic amino acid and subsequently coupled to N-(1-naphthyl) ethylenediamine to form the color of the strip. The color intensity is proportional to the concentration of dissolved nitrates in the solution [6].

Niguyen and Angeles [17] carried out two experiments to determine the changes of the nitrate concentration in pineapple; the experiments were established to determine the samples protocols and to establish the critical values of $\mathrm{NO}_{3}$ in sap related to $\mathrm{NO}_{3}$ of the sap leaf and the vegetative yield. A Merkowuant nitrate was used, including $\mathrm{NO}_{3}$, and total $\mathrm{N}$ in tissue; this increases with levels of fertilization of N. The $\mathrm{NO}_{3}$ of the sap increases during the 14:00 and 16:00 hours, as the level of fertilizer increases from 0 to $16 \mathrm{~g}$. The plant increases the $\mathrm{NO}_{3}$ and the total content of $\mathrm{N}$ of dry tissue. The $\mathrm{NO}_{3}$ in sap was correlated with the total content of $\mathrm{N}$, obtaining $R=0.82$, and with the dry sap $\mathrm{NO}_{3}$, obtaining $r=0.91$. The content of $\mathrm{NO}_{3}$ varies from 397.33 to 418.21 and in dry tissue from $2282.76 \mathrm{ppm}$ to $2490.96 \mathrm{ppm}$. Niguyen and Angeles [17] concluded that there will be need of more studies to establish the critical value of $\mathrm{NO}_{3}$ in sap to validate the data and if it is possible to predict the necessities of N. A limitation of the strips of nitrate is its sensitivity to temperature that goes from a range of 6 to $30^{\circ} \mathrm{C}[6]$.

2.3. Chlorophyll Meters. The chlorophyll meter (SPAD) is a portable and easy-to-use instrument; it is not a destructive method and is functional to estimate, quickly, the nitrogen status of the crops; however, the chlorophyll meter is an instrument that measures indirectly the concentration of total nitrogen [18]. Several noninvasive methods have been developed in order to be applied in crops and to determine the nitrogen status of the plants. The majority of these methods calculate the nitrogen based on optical properties of the plants, which are affected by several factors such as water content, foliar senescence, diseases, vegetal nutrients, and nitrogen status within the plant [9].

The chlorophyll measurements do not interfere with the result over an excess of nitrates in vegetables, because there 
are nitrates that immediately are accumulated in the leaves that are assimilated later; therefore, this accumulation is used as indicator of nitrogen instead of assimilated nitrogen [6].

Rorie et al. [18] correlated the chlorophyll values with the concentration of foliar nitrogen where a mean of 0.78 was obtained and a mean of 0.83 was obtained for all parts of the leaves. This high relation is in agreement with the previous work [19], whereas value of 0.84 for the correlation among a chlorophyll meter SPAD and the foliar concentration in leaves of corn was found. This leads us to think that chlorophyll meters could be used to fix the nitrogen deficiencies. Also, Liu et al. [20] accomplished studies with SPAD to estimate chlorophyll and the content of nitrogen in leaves, where it can be concluded, as the aforementioned work, that it is possible to estimate the chlorophyll content in the plants; however, even though there exists correlation among SPAD measurements and the nitrogen content during August $(p<$ $0.05)$, in November, there were no significant correlations among nitrogen and SPAD measurements.

2.4. Optical Sensors Based on Fluorescent Dyes. Recently, research has been focused on optical sensors of nitrates based on the use of chloride of ammonium methyl tridecyl (TDMACI) as an ion selector; this compound is highly selective for chloride ion that is commonly in water and is used to avoid its interference [21].

Kim et al. [14] carried out studies for developing an optical sensor of nitrates based on disposable thin film. The sensor was fabricated by a nitrate-selective polymerase membrane on the surface of a polyester thin film. The membrane was composed of chloride of polyvinyl (PVC), fluorescent dye, and an ionophore selector. The intensity of fluorescence increased at the moment of contact with the nitrate solution. The response of the fluorescence of optical sensor was quantified through a commercial fluorescence meter. The optical sensor shows a lineal response through the four samples of ten repetitions. It was concluded that the concentrations of nitrates in nutritious solutions can be determined by optical measurements without any restrictions before the measurements; however, this kind of technologies is not able yet of disposing devices that integrate the chlorophyll quantification.

Dudwadkar et al. [22] use the method of anions interchange chromatography for quantifying nitrates through the detection of conductivity in suppression mode. A relative standard deviation of $5 \%$ was obtained and the limit of detection for the determination of nitrates was $0.02 \mu \mathrm{g} \mathrm{mL} L^{-1}$. The method has high performance and analyzed 6 samples per hour. There were no interferences of impurities such as chloride and sulphate. The limit of detection for the determination of nitrate was $0.02 \mathrm{~g} \mathrm{~mL}^{-1}$ and the relative standard deviation was $5 \%$ for the general method.

2.5. Biosensors. The biosensors generally are defined as devices that consist of a bioreceptor and a mechanism of signal transduction able of producing a measurable signal in the presence of an analyte [23]. The term biosensor has been adopted by several technologies and can be qualitative and quantitative and also can be devices that employ genetically modified organisms (GMOs) or physical devices. This kind of sensors recognizes, through the receptor, biochemical or physiological changes based on a system of signal transformation that is evaluated later [24] (see Figure 1). This term varies according to the applied approach and it could be qualitative or quantitative, physical devices, or transgenic cells, which eventually have a biological receptor that serves as signal recognizer detecting biochemical or physiological changes; eventually, a system of signal transformation is used to convert an event raised in a measurable signal [24].

Nowadays, the technology allows us to fuse an element with reporter gene to generate a cellular biosensor [10]. The proteins that emit fluorescence have been used as markers and as reporter genes to study the performance of proteins at cellular level and also used to measure, internally, the activity of a promoter in tissue [25]. When the gene of a protein is used as a transcription reporter, typically, a bioluminescent or fluorescent protein such as luciferase or the GFP [10], a cellular promoter, leads to the expression of the reporter gene, resulting in a measurable signal that reflects the expression of the promoter (see Figure 1). One of the bacteria that are used to be modified genetically to realize this gene expression is Escherichia coli (E. coli), where the aforementioned gene constructs have been tested; thus, the intensity of luminescence or fluorescence is directly proportional to the concentration of the analyte of interest (Figure 2).

There is great diversity of biosensors; however, highlight those based on immobilized enzymes located on the electrode which gives an electronic signal [26]. As mentioned above, proteins that emit fluorescence have been used as specific markers and as reporter genes for studying the performance of the proteins at cellular level [22]. When the gene is used as a reporter of transcription, a cellular promoter conducts to the expression of the reporter gene, resulting in a measurable signal that locally reflects the expression of the promoter. Commonly, this gene expression system is presented in the cell of E. coli.

\section{Promoter Genes Sensible to Nitrates}

There are a lot of promoter genes that can be used to build reporter bacteria for detecting some environmental change or several compounds, specifically, the detection of different forms of nitrogen presented in aquatic and terrestrial ecosystems [27]. Table 1 presents advantages and disadvantages of gene promoter that can be used as sensing element of any nitrogen source.

3.1. $g \ln A$. The $g \ln A$ promoter that controls an operon of essential genes implied in the ammonium issues in Life Sciences Bacteriology, Parasitology, and Virology Acton assimilation (glutamine synthetase GS) [28] by amidation of glutamate for producing glutamine [29] has moderate activity under limiting conditions of nitrogen during exponential phase and is independent of nitrogen levels [28]; it is activated 
TABLE 1: Advantages and disadvantages of gene promoters that can be used as a sensing element of any nitrogen source.

\begin{tabular}{|c|c|c|c|}
\hline Gene & Enzyme & Advantages & Disadvantages \\
\hline$g \ln A$ & Synthetase glutamine & $\begin{array}{l}\text { It could detect a wide range of } \\
\text { concentration of ammonium in } \\
\text { plants }\end{array}$ & $\begin{array}{l}\text { A disadvantage is that it can } \\
\text { respond to amino acids and other } \\
\text { nitrogenous compounds }\end{array}$ \\
\hline nirA & p-Hydroxyphenylpyruvate dioxygenase & $\begin{array}{l}\text { It is induced in the presence of } \\
\text { nitrate }\end{array}$ & $\begin{array}{l}\text { It is repressed in the presence of } \\
\text { ammonium }\end{array}$ \\
\hline GifA & Synechocystis NtcA & $\begin{array}{l}\text { It is induced in the presence of } \\
\text { ammonium }\end{array}$ & $\begin{array}{l}\text { It is repressed in the presence of } \\
\text { combined nitrogen }\end{array}$ \\
\hline nitA & Nitrilase & $\begin{array}{l}\text { It is activated by combining a source } \\
\text { of nitrogen ammonium nitrate }\end{array}$ & $\begin{array}{c}\text { Change of the nitrogen source } \\
\text { disrupts the growth and } \\
\text { development }\end{array}$ \\
\hline pyeaR & NsrR & $\begin{array}{l}\text { It is activated in the presence of } \\
\text { nitric oxide, nitrate, and nitrite }\end{array}$ & $\begin{array}{c}\text { It is repressed by two repressors, } \\
\text { Nar-regulated by nitrates and } \\
\text { nitrites, and NsrR-regulated by } \\
\text { nitric oxide }\end{array}$ \\
\hline
\end{tabular}

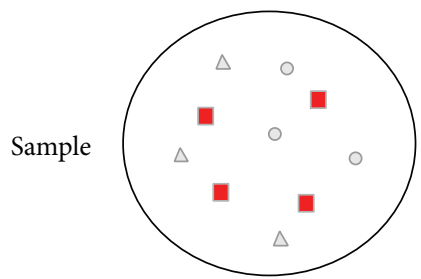

Exposure to sample
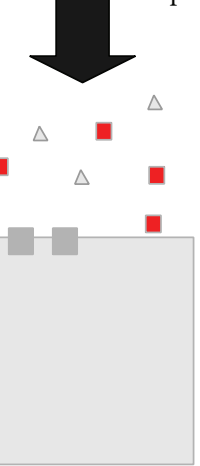

Receiver selective binding of analyte

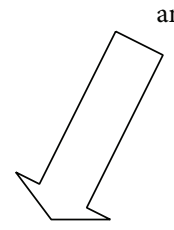

Catalytic

Cells

Tissue

Enzymes

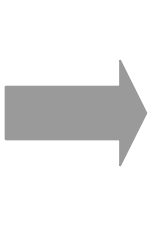

$$
\text { of }
$$

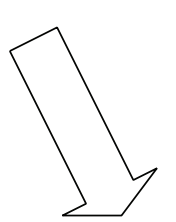

Affinity

Antibodies

Protein

Nucleic acids

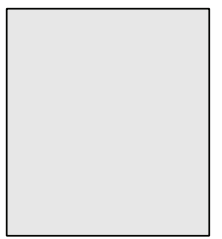

Transducer

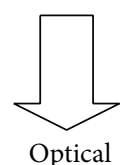

Electromechanical

Piezoelectric

Magnetic
Detector
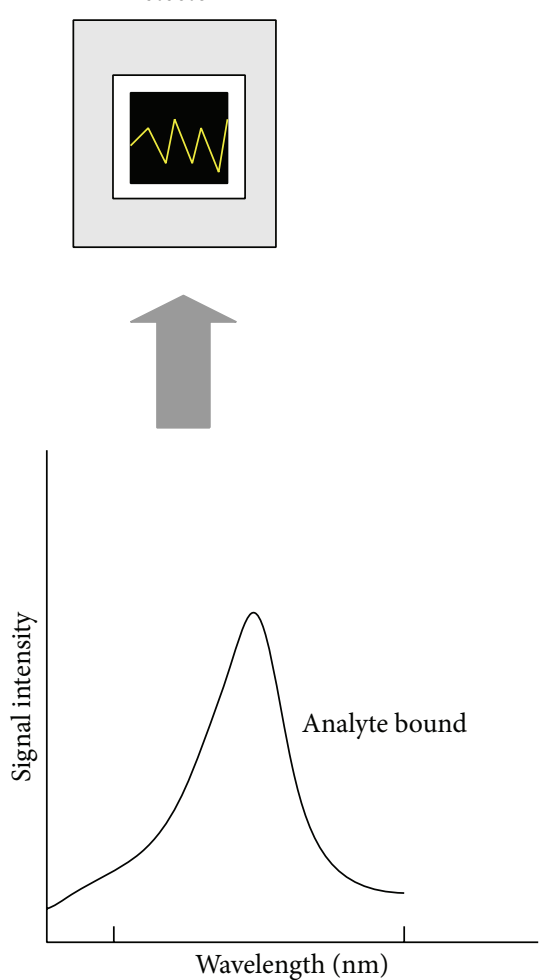

Analyte

Interference

FIGURE 1: Schematic diagram of a biosensor. A bioreceptor is used to provide specific chemical recognition. 


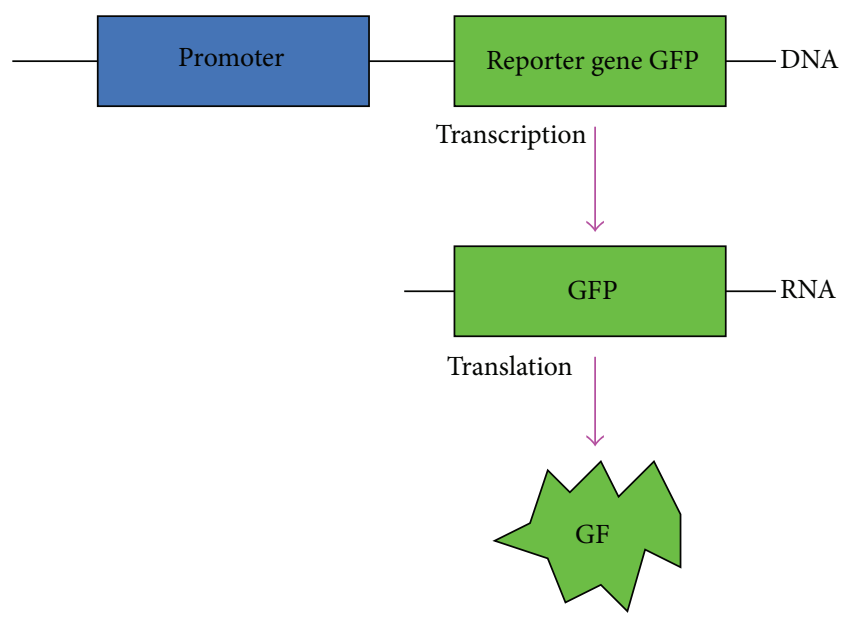

Figure 2: Reporter gene used to study a regulatory sequence.

in absence of different sources of nitrogen and responds linearly to the addition of known quantities of several nitrogen sources in the range of $50-500 \mathrm{mM} \mathrm{NH}_{4}{ }^{+} \mathrm{O} \mathrm{NO}_{3}{ }^{-}$[29].

3.2. nirA. The operon nirA is an intermediate for the assimilation of the nitrate reduction [30] and it is activated in presence of nitrate [28], in the absence of ammonium, and in the presence of nitrite [31]. It responds linearly in the gamma of 10-600 $\mathrm{nM} \mathrm{NH}_{4}{ }^{+}$[28]. When the nitrate is limited, the operon nirA becomes more sensible which leads to an increment of the activities of enzymes of nitrate assimilation [30]. Several positive actions of proteins needed for the expression of the operon nirA have been identified [31].

3.3. gifA. The promoter gifA is induced to be expressed in presence of ammonium, except in a medium that has different forms of nitrogen. GifA has a linear response going from 100 to $600 \mathrm{mM}$ [28]. Bren et al. [28] carried out experiments where the expression of the gen gifA is in the strain NGIF and was tested in a medium with ammonium, a nitrate solution, and a solution composed of various forms of nitrogen and the levels of expression were low in solutions composed of several nitrogen forms and also in nitrate solutions; nonetheless, they were activated significantly from 6 to 24 hours in the ammonium medium [28].

3.4. nitA. The promoter of the gene nitrate reductase (nitA) performs as a molecular interrupter that allows turning on the expression of the transgenic species; this expression is activated combining a source of nitrogen of ammonium to nitrate [32] and these actions have allowed the development of new molecular tools that will be useful in the future [32].

3.5. pyeaR. pyeaR is found in the operon yeaR/yoaG of the bacteria $E$. coli and it is activated in the presence of the nitric oxide, nitrates, and nitrites. This promoter is found repressed by two repressor, Nar (regulated by nitrates and nitrites) and $N s r R$ (regulated by the nitric oxide). PyeaR is not found active in aerobic conditions; it can be used as a biosensor under various conditions [33].

\section{Expression of Reporter Genes}

The reporters' genes commonly used are $L a c Z, \operatorname{lu} x C D A B E$, and $g c p$; however, the development of the investigation has allowed the increase of the use of other fluorescent proteins such as dsRed (RFP) among others [34]. Table 2 shows the advantages and disadvantages of the reporter genes commonly used.

4.1. Gfp. The fluorescent green protein (GFP) is derived from Aequorea victoria and it is the most studied and used; there are a lot of variants that have been developed starting from the modifications done in GFP [22]. The expression of the GFP does not serve only as indicator; also, it is an indicator of the membrane integrity [35]. The promoter of interest controls the expression of the fluorescent green protein (GFP) [28].

The $\mathrm{mFP}$ is a dependent variant of the florescent green protein because it was identified in nonbioluminescence pathogenic bacteria (Vibrio vulnificus CKM-1), through the expression of the mBFP or the fusion of $M b f p-m s 1 C$ evaluated in different subcellular compartments and tissues in three different plants. Dudwadkar et al. [22] showed that the protein $\mathrm{mBFP}$ is a reporter useful in plants which could be used as label to study the traffic of proteins and its localization.

A recombinant plasmid was introduced in the bacterium E. coli XL1-B and contains the reporter genes GFP y RFP, which were combined with the promoters zraP and cusC; it emits fluorescence in response to copper and zinc, resulting in an increasing of the fluorescence intensity [36]. The fluorescence emitted by RFP was low in cells exposed to zinc; however, brilliant red fluorescence was detected in cells exposed to copper; in the same way, the fluorescence of the GFP was low in the presence of zinc; nonetheless, brilliant green fluorescence under copper presence was detected. At the moment of combining these two elements (copper and zinc), the reporter genes were activated and showed yellow fluorescence. The construction of PCRGZ1 reporter detects, efficiently, low concentrations of $200 \mathrm{mM}$.

4.2. IacZ. The operon gene $L a c Z$ [37] is applied in cellular and molecular biology to solve genetic problems, recently, to attend emergent problems of genomics and proteomics, and it is used as a reporter gene due to its adaptation in the studies of promoter functions and the analysis of genetic expression. The expression of this protein could be used to detect the presence of substances in an environment, both in vivo and in vitro, based on the measurement of fluorescent products or colored derivatives [38].

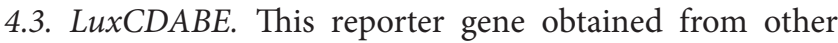
luminescent bacteria has been used due to its facility of being manipulated, sensibility, and its dynamic range of light measurement. This reporter gene produces a cellular signal 
TABLE 2: Advantages and disadvantages of gene reporters that can be used as a sensing element of any nitrogen source.

\begin{tabular}{|c|c|c|c|c|}
\hline Gene & Protein & Signal & Advantages & Disadvantages \\
\hline Gfp & $\begin{array}{l}\text { Green fluorescent } \\
\text { protein }\end{array}$ & $\begin{array}{l}\text { Green } \\
\text { fluorescence }\end{array}$ & $\begin{array}{c}\text { Multiple fluorophores } \\
\text { No diffusion } \\
\text { Does not affect the physiological } \\
\text { mechanism of cell } \\
\text { Compatible for translational fusins }\end{array}$ & $\begin{array}{l}\text { Moderate sensitivity } \\
\text { Temporal resolution } \\
\text { Fluorescence microscopy }\end{array}$ \\
\hline$L a c Z$ & $\beta$-galactosidase & $\begin{array}{l}\text { Fluorescence, } \\
\text { colored } \\
\text { molecules }\end{array}$ & $\begin{array}{l}\text { Can use inexpensive light } \\
\text { microscope }\end{array}$ & Requires reagent \\
\hline dsRed & Red fluorescent & $\begin{array}{c}\text { Red } \\
\text { fluorescence }\end{array}$ & $\begin{array}{l}\text { Can use inexpensive light } \\
\text { microscope }\end{array}$ & Moderate sensitivity \\
\hline CobA & $\begin{array}{l}\text { Uroporphyrinogen III } \\
\text { methyltransferase }\end{array}$ & $\begin{array}{c}\text { Red } \\
\text { Fluorescence }\end{array}$ & & Use fluorescence microscopy \\
\hline Luc & Luciferase (insect) & Light & $\begin{array}{c}\text { High sensitivity } \\
\text { Linear across several orders of } \\
\text { magnitude }\end{array}$ & Requires addition of coelenterazine \\
\hline LuxCDABE & Bacterial luciferase & Light & High sensitivity and dynamic range & Moderate sensitivity and linearity \\
\hline $\operatorname{LuxAB}$ & Bacterial luciferase & Light & $\begin{array}{c}\text { Its high sensitivity and dynamic } \\
\text { range, linear across }\end{array}$ & Requires addition of coelenterazine \\
\hline InaZ & Ice nucleation protein & Ice & $\begin{array}{c}\text { High sensitivity } \\
\text { Linear across } \\
\text { Excellent temporal resolution }\end{array}$ & Requires reagent \\
\hline
\end{tabular}

that helps to avoid the necessity of cellular disruption and enzymatic assays [39].

The development of new biosensors has been designed to transform an autotrophic bacterium E. coli through $g l n$ promoter (estandar, $g l n$ ) and an operon reporter gene, to a biosensor GlnLux [39]. The biosensor $G \ln L u x$ was tested in four different magnitudes, and linear measurements were obtained. For the calibration of the biosensor, a sensibility assay was done (signal: noise: ratio) and it was improved through the dilution of cultivation of the biosensor GlnLux to increase the availability of the gln per each cell. By employing these strategies, the biosensor GlnLux reaches a sensibility of $0.0001 \mu \mathrm{g} / \mathrm{mL}(0.68 \mathrm{nM})$; this is a similar range as the obtained with the HPLC-MS/MS.

4.4. $\operatorname{Lux} A B$. The system of bioluminescence contains five genes coming from the marine microorganism Vibrio Fisheri and was used by first time as expression gene in 1985 [40]. The lux genes were divided up in those to form a luciferase (LuxAB) and those required for synthesis of a large chain aldehyde (LuxCDE). The division of this system of five genes is much more effective than those using the complete operon lux (luxCDE + luxAB or simply luxAB); this was determined through the fusion of the gene $\operatorname{Kat} G$ with the purpose of measuring precisely the potential of oxidative stress; thus, the divided lux system has a better signal than the fused complete operon; however, the system that contains only luxAB has higher signal than the others.

4.5. InaZ. The gene reporter codifies a protein of nucleation of ice of some bacterial species, such as Pseudomonas syringae that are proteins of external membrane that catalyze the ice creation [41]. The dependent nucleation of nitrogen in two varieties of bacteria, E. coli DH5 and E. herbicola 299R, under anaerobic conditions that contain a fusion of the promotor gene narG with the reporter gene inaZ in a plasmid pNarg-Ice expresses activity of nucleation of ice that increases linearly with the increment of the concentration of nitrate in the interval that goes from $0.1 \mathrm{mM}$ to $10 \mathrm{mM}$ under anaerobic conditions [42].

4.6. Luciferase. Luciferase catalyzes a reaction (oxidation of benzothiazolyl-thiazide luciferin, magnesia, and oxygen) in order to create a reaction inside the range of 550 to $576 \mathrm{~nm}$ [43].

4.7. Green Fluorescent Protein (GFP) as Reporter Gene in a Genetically Modified Bacterium. The jellyfish Aequorea victoria formed by a protein that has the property of emitting green light has become in a useful tool to cellular biology [44]. The GFP is the protein that is formed by 238 amino acids [45]; this is the most studied and used, and there are several variants that have been developed by modifications of the GFP [22]. The promoter of interest controls the expression of the GFP [46].

Many proteins contain fluorescence proteins different of the sequence of the amino acid of the protein; the chromophore of the GFP is internally generated by a reaction of three amino acids [47]. The chromophore is formed by the spontaneous cyclization and the oxidation of the residues 6567, corresponding to amino acids Ser 65, Tyr 66, and Gly 67 of the native protein and it is responsible for the emission of green light [44]. This chromophore presents two peaks of excitation and emission; if it is exited at $395 \mathrm{~nm}$, it presents 


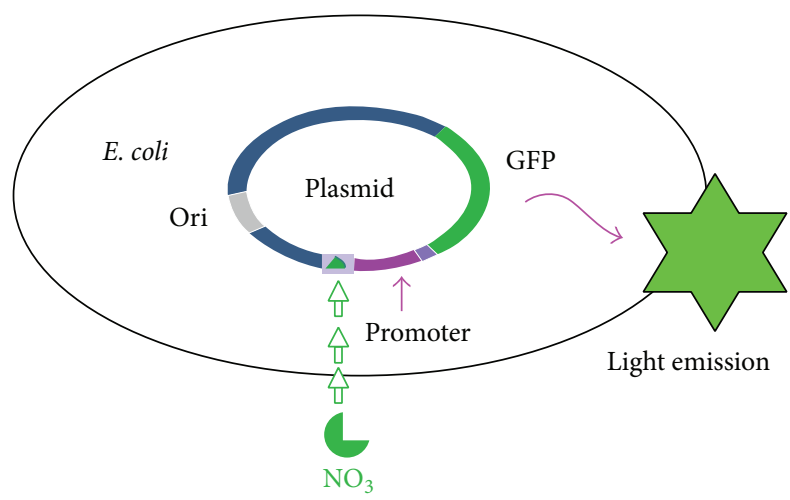

Figure 3: Basic principle of GFP microbial biosensors.

an emission peak of $508 \mathrm{~nm}$; if it is excited at $475 \mathrm{~nm}$, it presents a peak of emission of $503 \mathrm{~nm}$ [48]. To form the chromophore, a correct plication of the protein is necessary; if this plication is not achieved or makes an incorrect plication, the chromophore is not formed [47]. When the GFP reporter gene is used, it is attributed to a regulatory sequence of another gene (promoter); a promoter of interest is fused to coding region of the GFP that leads to the expression of the fluorescent protein resulting in a fluorescent [22] signal that temporally reflects the expression of a promoter in vivo [47].

The coding sequences of these fluorescent proteins in the plasmids are highly expressed in the system of the bacteria $E$. coli [11]; therefore, a correlation among fluorescence and the expression of the promoter of interest in bacteria genetically modified can be obtained. On the other hand, E. coli has been used as tool to detect large amounts of recombinant proteins [47]. Tsien [48] classifies the GFP as a passive application if it is used as marker fused to other proteins because it reflects the levels of expression of the protein or the subcellular location of this protein.

The biosensors based on fluorescence for the detection of nitrates have been reported. E. coli is transformed through a plasmid, where the promoter and the regulated regions of nitrates Pnar are fused to the GFP; the activity Pnar-gfp is measured in the range of concentrations of nitrates through the emission of the fluorescence of the GFP being the intensity of the fluorescence proportional to the concentration of extracellular nitrate without interference of other acceptors of electrons such as nitrites, dimethyl sulfoxide, trimethylamine n-oxide, and fumarate [10].

These gene constructs could be used to measure nitrates implants, because they present advantages with respect to the conventional sensors; because the GFP does not have affinity with divalent cations, the union and the elution of other proteins are not affected; the GFP results in an excellent indicator because it does not interfere with the physiological mechanism of the cell [12]; also, the interval of the $\mathrm{PH}$ of the purification process is maintained generally between 7 and 8 that is the optimal $\mathrm{pH}$ for the fluorescence of GFP; also, the high salinity conditions and the presence of imidazole are not factors that alter the stability or the fluorescence of GFP [11].

Figure 3 shows that the anatomy of a microbial biosensor for the determination of nitrates consists of transgenic

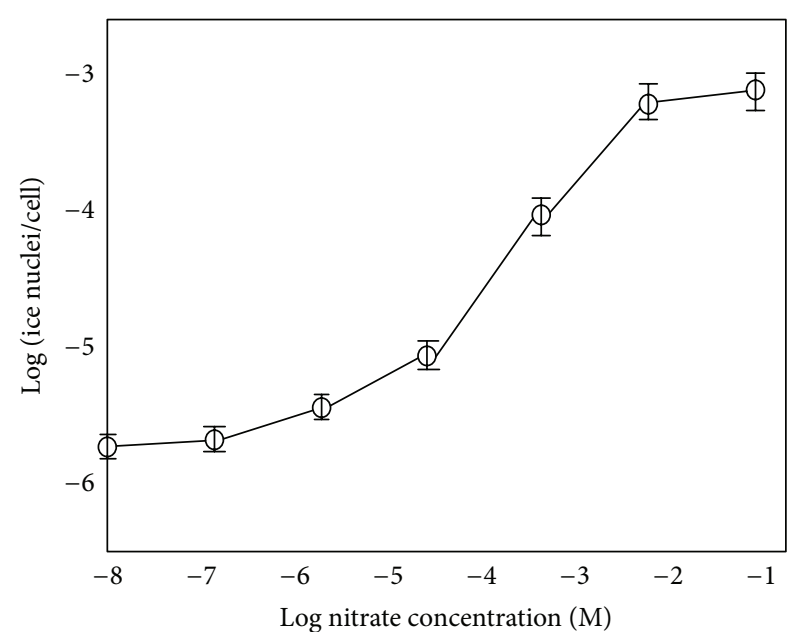

(a)

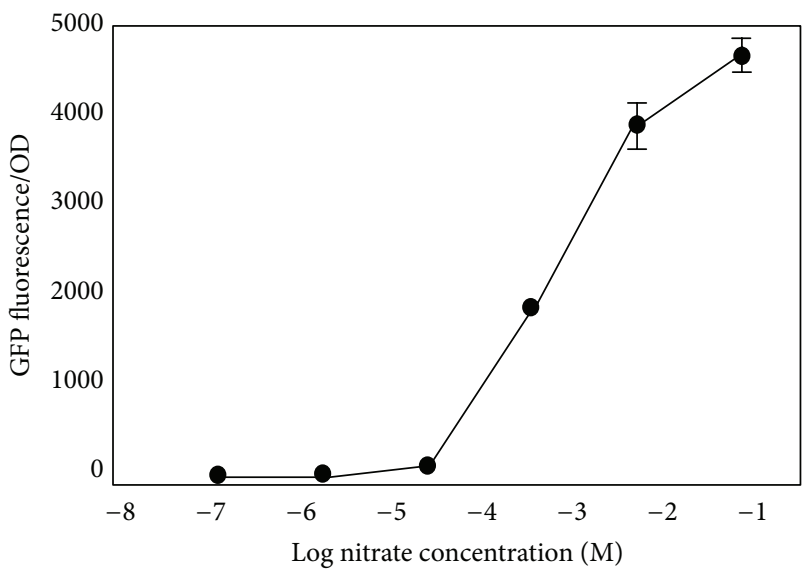

(b)

FIGURE 4: Ice nucleation activity of $E$. coli (pNice) and nitrate concentration (a). Fluorescence of cell cultures of E. cloacae (pNgfp) in minimal medium with different concentrations of nitrate. OD, optical density unit (b) [42].

E. coli-cell integrated in the genome as reporter gene GFP and sensible promoter gene nitrates [42]. Gene complex is transcribed into messenger RNA and then translated into a reporter protein that is ultimately responsible for generating a signal.

\section{Development of Biosensors Nitrate Meters}

These genetic transformations have been used to detect the availability of the nitrates in the ground around the roots. DeAngelis et al. report the development of two bacterial biosensors through Enterobacter cloacae (E. cloacae) and E. coli where the regulator promoter of nitrates in E. coli was fused to the promoterless ice nucleation (Inaz) and the reporter gene GFP through the plasmids pNice and $\mathrm{pNgfp}$, respectively. The fluorescence of the GFP in E. cloacae through $\mathrm{p} N g f p$ plasmid was uniform to a given concentration of nitrates with a relation of 1000 -fold when nitrate increased from 0 to $1 \mathrm{mM}$. The measurable induction of the nucleation of ice in E. cloacae through the plasmid pNice is given from 
$0.1 \mu \mathrm{M}$. The inaZ-based nitrate biosensor was responsive to nitrate concentrations about 10-fold lower (Figure 4) [42] which showed that the bacterial biosensors are useful to estimate the availability of nitrates in microbial niches in complex natural environments such as the rhizosphere.

There has been used the strain Synechococcus sp. FAM431 that contains the gene $g \ln N$ fused to the reporter gene luxAB. The work presented by Muñoz-Martín et al. [29] accomplishes genetic constructions through the plasmids Pbg2112, pB2110, and gen promoter nirA. Muñoz-Martín et al. [29] have based these genetic transformations to realize a bioreporter bacterium. The development of these genetic transformations allows for studying the responses of the promoters $g \ln A, N I R$, and gifA to the exposition to different sources of the nitrogen in the strains Nostoc sp. PCC 7120 that express the region of the promoter of these genes fused to the reporter genes luxCDABE of Xenorhabdus luminescens.

Muñoz-Martin et al. [29] use the strain Synechococcus elongatus PCC 7942 that expresses the promoter $g \ln N$ fused with the reporter genes luxABAs for detecting different forms of nitrogen in water; the results show that the promoter $g \ln N$ fused with $\operatorname{lu} x A B$ responds linearly in the range of $50-500 \mu \mathrm{M}$ of combined nitrogen; however, with the operon nir $A$, the range of expression in the presence of nitrogen was $100 \mu \mathrm{M}$ of $\mathrm{NO}_{3}$. These differences between the ranges can be attributed to different forms of nitrogen presented in water; that is similar to the results of the strain S. GLN. Another bioreporter bacterium based on the promoter $g \ln A q u e$ has the more reduced range of detection; it goes from 5 to $90 \mu \mathrm{M}$.

\subsection{Considerations for the Development of Biosensors for Nitrates Determination}

5.1.1. Immobilized Cell Systems. To develop biosensor of nitrates, it is necessary to provide systems for immobilizing cells; this helps to avoid problems associated with the growth of cell population [49]. Cell immobilization refers to confined and located cells, retaining their catalytic activities. These cells can be immobilized permanently or temporarily in order to be used repeatedly in various chemical processes [50].

The considered criteria for conditions of detention are determined to build strong granules, high substrate transfer rates, and low rates of cell leakage [51]. The advantages of biotech systems based on immobilized cells are their ease of handling high density cells, improvement of the control in continuous systems, and the recovery of biomass for reuse [50].

One of the methods used to immobilize cells is the preparation of macroporous solids using porous materials synthesized by unidirectional freezing and subsequent lyophilization [50]. Hydrogel materials have been used as an immobilization matrix cell. The high viscosity pre-gelled solutions used in these applications decrease cell viability due to the shear forces required for mixing the cells with these solutions, which is associated with decreasing the molecular weight of polymer used for the gel capacity; it enables gelation. Immobilization of cells with alginate hydrogels allows for increased cell viability of $40 \%$ to $70 \%$ compared with the use of polymer chains to form high molecular weight gels [52].

To immobilize cells of $E$. coli (concentrated aqueous suspension of $E$. coli bacteria) within a polymeric matrix, calcium alginate and glucose have been used by freeze-drying technique; the resulting matrix that is a porous matrix of polyvinyl alcohol bacteria is retained in such a way that is able to detect specific molecules from an environment [50].

5.1.2. Fluorescence Measurement System. Considering the development of biosensors for nitrates, common E. coli is modified to make these bacteria specifically express genes (i.e., luminescence or fluorescence produced by the expressed gene) in response to nitrates presence in the medium. Luminescence or fluorescence intensity of the fluorescent protein is directly proportional to the nitrates concentration; thus, it will require fluorescence detection systems that allow for making a correlation between nitrates and the emitted fluorescence [10], since fluorescence sensors are an attractive target for the development of a new generation of detection systems for nitrates since the methodologies based on fluorescence are more sensitive and easier to apply than current technologies [53].

Fluorescence is a phenomenon that occurs in various biological processes and systems where molecules absorb and emit radiation in a spectral range of 475 and 508 nanometers (nm) [54]. This phenomenon has become a powerful tool in investigations in studies at the molecular level and dynamics of living systems [55]. If a fluorescent sample with adequate power is irradiated, the molecules absorb such energy; this energy enables movement of a valence electron from the ground state GSO (being an electronic singlet where electrons have opposite spin and net twist is 0 a higher energy level) to an excited state ESn [56]. After the emission of the photon, the molecule returns to its ground state [57]. Photon emission accompanying the passage at vibrational level is a spontaneous process called fluorescence [55].

Several studies have enabled the development of new small and cheap fluorometers by using light emitting diodes (LEDs) that turn blue sign [54] where results were found favorable.

Given these considerations, using systems in bacterial fluorescence measurement based biosensors builder complementary DNA (reporter gene (GFP) and a promoter gene sensitive to nitrates in an expression vector in prokaryotic cells (E. coli) [58]), is possible to develop a system quantizer fluorescence to determine the amount of nitrates in a solution.

\section{Perspectives}

There are biosensors based on gene constructions that indicate the concentration of nitrates; this occurs when a complementary DNA and the promoter gene are inserted in procaryotic cells [58]; this quantification is accomplished through fluorescence correlation. The response to these kind of biosensors is being commonly employed due to its sensibility and versatility [13]; the intensity of fluorescence is 


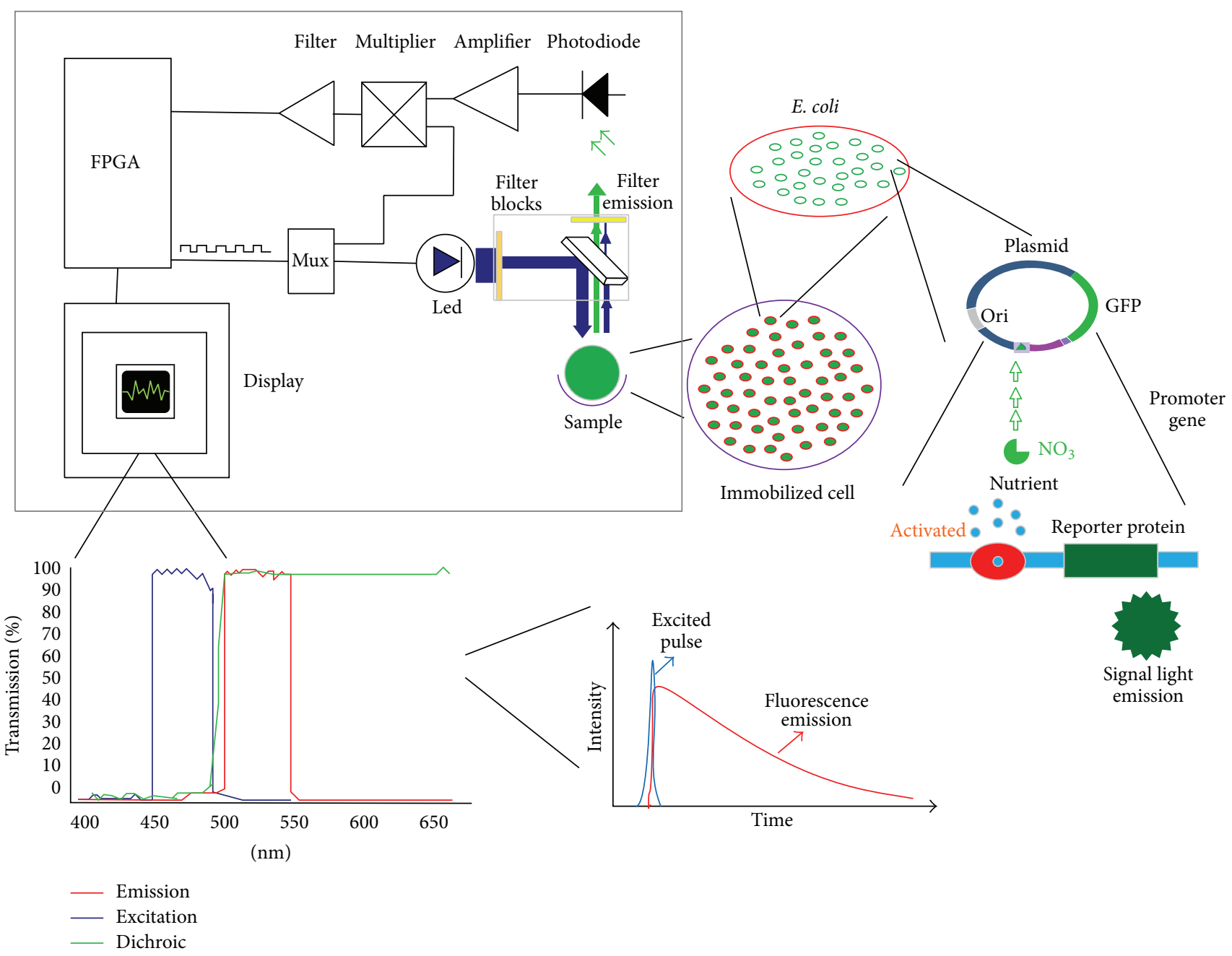

FIGURE 5: Integration of the necessary elements for the design of biosensors for nitrates.

proportional to the concentration of the extracellular nitrates [10].

This review provides necessary information and gives guidelines for the integration of biological and electronic systems for developing biosensors for nitrates detection and quantification using a fluorescence detection system (Figure 5). The latter could be composed of a processing unit; in fact, there are currently biological processes units using processing units [59]; one of them are the FPGA (Field Programmable Gate Arrays). FPGAs have been used for developing processing systems for correlation spectrometry in radio astronomy [60]. The use of these devices in the area of biosystems is becoming popular mainly due to their high reconfigurability and SoC (System on a Chip Solutions). The methodology proposed here is the following: the processing unit (FPGA) sends pulses to LEDs with emission spectrum of $475 \mathrm{~nm}$, directing the light through the emission filter that only allows the passage of emission spectrum generated by the LED [54]; often, a dichroic mirror directs the light from the LED to the sample; the genetically modified bacteria with the GFP gene are excited by the incidence of the light and fluoresces in the range of $508 \mathrm{~nm}$; an excitation filter of $508 \mathrm{~nm}$ only allows the passage of the light in the range of $508 \mathrm{~nm}$. The fluorescence emission will be assessed by a photodiode which converts the number of photons received in a corresponding number of electrons [61]. The electrons will be moved to a conduction band generating a photo-current; this photo-current is converted to a voltage by signal conditioning system and, later, this signal is sent to an analog-digital converter. Finally, the processing unit receives this signal in order to process it [62]. Quantification process could be possible if promoters are sensible to other compounds, and the reporter genes are identified, and by combining both, the researchers could obtain a quantitative relation of the emitted fluorescence and the quantity of the compound under analysis. To use these biosensors, it is necessary to perform a standardized protocol and design a strategy involving cell structure by a reporter and receiver nitrates gene [10]; according to the review, these biosensors could be disposable by using encapsulated agarose pellets or sodium alginate as cell immobilization tool in order to avoid the problems of increase in bacterial population or population decay [49]. These cell structures (bacteria) will be replaced when a new measurement is made; one 
that promises portability equipment has the ability to store the bacterial biosensors with the sample being required to measure. Finally, the use of the fluorescence emitted by GFP produced by the open reading frame coupled to a responsive promoter nitrates allows estimation of their concentration in solution using a mathematical model involving nitrate concentration and intensity of fluorescence; this model could be obtained using a mathematical regression model.

Unlike other methods, there are works where the interferences by ions and external factors alter the measurements, and these disadvantages could be avoided if biosensors based on gene constructions are used [10]. However, gene construction based biosensor takes more time to be prepared because there are no devices based on gene constructions that measure the nitrates in versatile form [13]. This kind of devices could be developed commonly because the principle of fluorescence is known. Nonetheless, based on this principle, it would be possible that the researchers could develop more of these kind of sensors not only for nitrate.

\section{Conclusions}

The development of biosensors based on constructions genetically modified that could indicate, quantitatively, the quantity of nitrogen has been a breakthrough and step by step is becoming a robust tool with high potential for being used in crops because of the advantages of not interfering with the physiological mechanism of the cells [12], and the problems, such as those generated by carriers ions, the union, and elution of proteins, are avoided by using this kind of biosensors. Also, high salinity conditions and the presence of imidazole are no factors that interfere with the measurements of this kind of biosensors [11]; therefore, it is thought that genetically modified biosensors are the future of measurement systems, because apparently by using this approach, great diversity of sensors could be developed.

\section{Conflict of Interests}

The authors declare that there is no conflict of interests regarding the publication of this paper.

\section{Acknowledgments}

The authors would like to thank CONACYT for the financial support (scholarship 304825), Fondo de Fortalecimiento a la Investigación FOFIUAQ-2013 for the financial support, and FORDECYT (193512).

\section{References}

[1] J. V. Sinfield, D. Fagerman, and O. Colic, "Evaluation of sensing technologies for on-the-go detection of macro-nutrients in cultivated soils," Computers and Electronics in Agriculture, vol. 70, no. 1, pp. 1-18, 2010.

[2] L. Taiz and E. Zeiger, Plant Physiology, Sinauer Associates Inc, Sunderland, Mass, USA, 2010.

[3] M. Barrios, J. Garcia, and C. Basso, "Efecto de la fertilización nitrogenada sobre el contenido de nitrato y amonio en el suelo y la planta de maíz," Bioagro, vol. 23, no. 3, pp. 213-220, 2012.
[4] N. Vigneau, M. Ecarnot, G. Rabatel, and P. Roumet, "Potential of field hyperspectral imaging as a non destructive method to assess leaf nitrogen content in Wheat," Field Crops Research, vol. 122, no. 1, pp. 25-31, 2011.

[5] S. Boudsocq, A. Niboyet, J. C. Lata et al., "Plant preference for ammonium versus nitrate: a neglected determinant of ecosystem functioning?" The American Naturalist, vol. 180, no. 1, pp. 60-69, 2012.

[6] S. E. Parks, D. E. Irving, and P. J. Milham, "A critical evaluation of on-farm rapid tests for measuring nitrate in leafy vegetables," Scientia Horticulturae, vol. 134, pp. 1-6, 2012.

[7] R. F. Muñoz-Huerta, R. G. Guevara-Gonzalez, L. M. ContrerasMedina, I. Torres-Pacheco, J. Prado-Olivarez, and R. V. Ocampo-Velazquez, "A review of methods for sensing the nitrogen status in plants: advantages, disadvantages and recent advances," Sensors, vol. 13, no. 8, pp. 10823-10843, 2013.

[8] R. B. Thompson, F. M. Padilla, M. Peña-Fleitas, M. Gallardo, and M. M. Fernández Fernández, "Uso de sistemas de análisis rápidos para mejorar el manejo del nitrógeno en cultivos hortícolas," 2014, http://www.interempresas.net/Horticola/Articulos/130279-Uso-sistemas-analisis-rapidos-para-mejorar-manejo-del-nitrogeno-cultivos-horticolas.html.

[9] B. J. Zebarth, C. F. Drury, N. Tremblay, and A. N. Cambouris, "Opportunities for improved fertilizer nitrogen management in production of arable crops in eastern Canada: a review," Canadian Journal of Soil Science, vol. 89, no. 2, pp. 113-132, 2009.

[10] C. J. Taylor, L. A. Bain, D. J. Richardson, S. Spiro, and D. A. Russell, "Construction of a whole-cell gene reporter for the fluorescent bioassay of nitrate," Analytical Biochemistry, vol. 328, no. 1, pp. 60-66, 2004.

[11] L. Chang-Hun, "Experimental note: recombinant green fluorescent protein derivatives as a fusion tag for in vitro experiments," Interdisciplinary Bio Central, vol. 1, pp. 1-15, 2009.

[12] C. Fernandez, B. Domingo, F. Picazo, P. Tranque, and J. Llopis, "Análisis de la dinámica celular con proteínas fluorescentes," Universidad de Castilla La Mancha, Revista Científica de Divulgación, no. 5, 2006.

[13] A. Cheng Vollmer and T. K. Van Dyk, "Stress responsive bacteria: biosensors as environmental monitors," Advances in Microbial Physiology, vol. 49, pp. 131-174, 2004.

[14] G. Y. Kim, K. A. Sudduth, S. A. Grant, and N. R. Kitchen, "Disposable nitrate-selective optical sensor based on fluorescent dye," Journal of Biosystems Engineering, vol. 37, no. 3, pp. 209-213, 2012.

[15] E. Brambilla, N. Kloster, A. Bono, and J. Camiña, "Evaluación de métodos para determinar nitrato en suelo," Ciencia del Suelo, vol. 31, no. 2, pp. 245-252, 2013.

[16] F. Di Gioia, E. H. Simonne, M. Gonnella, P. Santamaria, A. Gazula, and Z. Sheppard, "Assessment of ionic interferences to nitrate and potassium analyses with ion-selective electrodes," Communications in Soil Science and Plant Analysis, vol. 41, no. 14, pp. 1750-1768, 2010.

[17] N. T. Niguyen and D. E. Angeles, "Foliar sap NO3-N in pineapple [Ananas comosus (L.) Merr.] at varying $\mathrm{N}$ levels and its relation with dry matter yield," Asia Life Sciences, vol. 21, no. 2, pp. 609-623, 2012.

[18] R. L. Rorie, L. C. Purcell, M. Mozaffari et al., "Association of 'Greenness' in corn with yield and leaf nitrogen concentration," Agronomy Journal, vol. 103, no. 2, pp. 529-535, 2011.

[19] M. Rostami, A. R. Koocheti, M. N. Mahallati, and M. Kafi, "Evaluation of chlorophyll meter (SPAD) data for prediction 
of nitrogen status in corn (Zea mays L.)," American-Eurasian Journal of Agricultural and Environmental Science, vol. 3, no. 1, pp. 79-85, 2008.

[20] Z. A. Liu, J. P. Yang, and Z. C. Yang, "Using a chlorophyll meter to estimate tea leaf chlorophyll and nitrogen contents," Journal of Soil Science and Plant Nutrition, vol. 12, no. 2, pp. 339-348, 2012.

[21] C. Huber, I. Klimant, C. Krause, T. Werner, and O. S. Wolfbeis, "Nitrate-selective optical sensor applying a lipophilic fluorescent potential-sensitive dye," Analytica Chimica Acta, vol. 449, no. 1-2, pp. 81-93, 2001.

[22] A. Dudwadkar, N. Shenoy, J. M. Joshi, S. D. Kumar, H. Rao, and A. V. R. Reddy, "Application of ion chromatography for the determination of nitrate in process streams of thermal denitration plant," Separation Science and Technology, vol. 48, no. 16, pp. 2425-2430, 2013.

[23] G. K. Knof and A. S. Bassi, Smart Sensor Technology, Optical Science and Engineering, CRC Press, New York, NY, USA, 2006.

[24] A. Sadanandom and R. M. Napier, "Biosensors in plants," Current Opinion in Plant Biology, vol. 13, no. 6, pp. 736-743, 2010.

[25] T. Jin-Min, C. Ming-Chung, L. L. Huang et al., "The blue fluorescent protein from Vibrio vulnificus CKM-1 is a useful reporter for plant research," Botanical Studies, vol. 55, article 79, 2014.

[26] M. Kato, J. Z. Zhang, N. Paul, and E. Reisner, "Protein film photoelectrochemistry of the water oxidation enzyme photosystem II," Chemical Society Reviews, vol. 43, no. 18, pp. 6485-6497, 2014.

[27] A. Herrero, A. M. Muro-Pastor, and E. Flores, "Nitrogen control in cyanobacteria," Journal of Bacteriology, vol. 183, no. 2, pp. 411425, 2001.

[28] A. Bren, Y. Hart, E. Dekel, D. Koster, and U. Alon, "The last generation of bacterial growth in limiting nutrient," $B M C$ Systems Biology, vol. 7, no. 1, article 27, 2013.

[29] M. A. Muñoz-Martín, P. Mateo, F. Leganés, and F. FernándezPiñas, "A battery of bioreporters of nitrogen bioavailability in aquatic ecosystems based on cyanobacteria," Science of the Total Environment, vol. 475, pp. 169-179, 2014.

[30] M. Aichi, S.-I. Maeda, K. Ichikawa, and T. Omata, "Nitriteresponsive activation of the nitrate assimilation operon in cyanobacteria plays an essential role in up-regulation of nitrate assimilation activities under nitrate-limited growth conditions," Journal of Bacteriology, vol. 186, no. 10, pp. 3224-3229, 2004.

[31] Q. A. Acton, Issues in Life Science-Bacteriology, Parasitology and Virology, Scholary Editions, Atlanta, Ga, USA, 2012.

[32] E. L. von der Heyde, B. Klein, L. Abram, and A. Hallmann, “The inducible nitA promoter provides a powerful molecular switch for transgene expression in Volvox carteri," BMC Biotechnology, vol. 15, no. 1, article 5, 2015.

[33] R. Dobson, J. EdwardsHicks, R. Gritton et al., Characterization of a Rationally Engineered Nitric Oxide, Nitrate and Nitrite Biosensor Linked to a Hybrid Bacterialmammalian, School of Biological Sciences, Wokingham, UK, 2015.

[34] B. P. H. Pulsen, L. Hansen, and S. J. Sorensen, "Biosensors to monitor soil health or toxicity," in Modern Soil Microbiology, J. D. van Elsas, J. K. Jansson, and J. T. Trevors, Eds., CRC Press, Boca Raton, Fla, USA, 2007.

[35] K. M. Polizzi and C. Kontoravdi, "Genetically-encoded biosensors for monitoring cellular stress in bioprocessing," Current Opinion in Biotechnology, vol. 31, pp. 50-56, 2015.
[36] S. Ravikumar, I. Ganesh, I.-K. Yoo, and S. H. Hong, "Construction of a bacterial biosensor for zinc and copper and its application to the development of multifunctional heavy metal adsorption bacteria," Process Biochemistry, vol. 47, no. 5, pp. 758-765, 2012.

[37] B. W. Matthews, "The structure of E. coli $\beta$-galactosidase," Comptes Rendus Biologies, vol. 328, no. 6, pp. 549-556, 2005.

[38] I. G. Serebriiskii and E. A. Golemis, "Uses of lacZ to study gene function: evaluation of $\beta$-galactosidase assays employed in the yeast two-hybrid system," Analytical Biochemistry, vol. 285, no. 1, pp. 1-15, 2000.

[39] M. J. Tessaro, Cell bacterial biosensor for glutamine and applications to plants and microbes [Doctoral Dissertation], University of Guelph, Guelph, Canada, 2012.

[40] J. Engebrecht, M. Simon, and M. Silverman, "Measuring gene expression with light," Science, vol. 227, no. 4692, pp. 1345-1347, 1985.

[41] S. E. Lindow, "The role of bacterial ICE nucleation in frost injury to plants," Annual Review of Phytopathology, vol. 21, no. 1, pp. 363-384, 1983.

[42] K. M. DeAngelis, P. Ji, M. K. Firestone, and S. E. Lindow, “Two novel bacterial biosensors for detection of nitrate availability in the rhizosphere," Applied and Environmental Microbiology, vol. 71, no. 12, pp. 8537-8547, 2005.

[43] C. H. Contag, D. Jenkins, P. R. Contag, and R. S. Negrin, "Use of reporter genes for optical measurements of neoplastic disease in vivo," Neoplasia, vol. 2, no. 1-2, pp. 41-52, 2000.

[44] A. Y. Franco and M. Longart, "Aplicaciones de la proteína verde fluorescente (GFP) en la biología celular y en la visualización del sistema nervioso," Redalyc, vol. 1, no. 2, pp. 84-96, 2009.

[45] M. Ormö, A. B. Cubitt, K. Kallio, L. A. Gross, R. Y. Tsien, and S. J. Remington, "Crystal structure of the Aequorea victoria green fluorescent protein," Science, vol. 273, no. 5280, pp. 1392-1395, 1996.

[46] A. Bren, Y. Hart, E. Dekel, D. Koster, and U. Alon, "The last generation of bacterial growth in limiting nutrient," $B M C$ Systems Biology, vol. 7, article 27, 9 pages, 2013.

[47] D. E. Crone, C. Schenkelberg, C. Bystroff et al., "GFP-based biosensors," in State of the Art in Biosensors-General Aspects, InTech Open Access, 2013.

[48] R. Y. Tsien, “The green fluorescent protein," Annual Review of Biochemistry, vol. 67, pp. 509-544, 1998.

[49] K.-C. Chen, C.-Y. Chen, J. W. Peng, and J.-Y. Houng, "Real-time control of an immobilized-cell reactor for wastewater treatment using ORP," Water Research, vol. 36, no. 1, pp. 230-238, 2002.

[50] R. Fernando-Ochoa, J. Osuna-Castro, C. V. Velazque-Mendoza, P. Escalante-Minakata, and V. Ibarra-Junquera, "Inmovilización de células y enzimas," Revista Cientifica de la Universidad Autonoma de Coahuila, vol. 3, no. 6, pp. 42-56, 2011.

[51] P. S. J. Cheetham, K. W. Blunt, and C. Bocke, "Physical studies on cell immobilization using calcium alginate gels," Biotechnology and Bioengineering, vol. 21, no. 12, pp. 2155-2168, 1979.

[52] H. J. Kong, M. K. Smith, and D. J. Mooney, "Designing alginate hydrogels to maintain viability of immobilized cells," Biomaterials, vol. 24, no. 22, pp. 4023-4029, 2003.

[53] Burdette and Cardon, "Development of a new generation of sensitive, fluorescence-based nitrate sensors for use in soil and water," Report as of FY2008 for 2007CT130B, Project 2007CT130B, 2008.

[54] J. F. Pavoni, W. F. Neves-Junior, M. A. Spiropulos, D. Ara, and D. Araúujo, "Uma montagem experimental para a medida de 
fluorescencia," Revista Brasileira de Ensino de Física, vol. 36, no. 4, p. 4501, 2014.

[55] B. Valeur, Molecular Fluorescence: Principles and Applications, Wiley-VCH, Weinheim, Germany, 2001.

[56] H. C. Ishikawa-Ankerhold, R. Ankerhold, and G. P. C. Drummen, "Advanced fluorescence microscopy techniques-FRAP, FLIP, FLAP, FRET and FLIM," Molecules, vol. 17, no. 4, pp. 40474132, 2012.

[57] W. Becker, "Fluorescence lifetime imaging-techniques and applications," Journal of Microscopy, vol. 247, no. 2, pp. 119-136, 2012.

[58] M. Y. Chalfie, Y. Tu, G. Euskirchen, W. W. Ward, and D. C. Prasher, "Green fluorescent protein as a marker for gene expression," Science, vol. 263, no. 5148, pp. 802-805, 1994.

[59] L. M. Contreras-Medina, Procesamiento de imágenes con FPGA para el modelado cuantitativo del síndrome del virus mosaico del pepino en Cucumis sativus [Tesis de Doctorado], Universidad Autonoma de Querétaro, 2012.

[60] S. M. A. Cuevas, Diseño de un Sistema de Procesamieno para Correlación y Espectrometría en Radioastronomía, Basado en ASIC y FPGA, Universidad de Chile, Facultad de Ciencias Físicas y Matemáticas, 2010.

[61] J. J. Lamb, J. J. Eaton-Rye, and M. F. Hohmann-Marriott, "An LED-based fluorometer for chlorophyll quantification in the laboratory and in the field," Photosynthesis Research, vol. 114, no. 1, pp. 59-68, 2012.

[62] H.-J. Yoon and S. Kawahito, "A CMOS image sensor for fluorescence lifetime imaging," in Proceedings of the 5th IEEE Conference on Sensors, vol. 22, pp. 400-403, Daegu, South Korea, October 2006. 


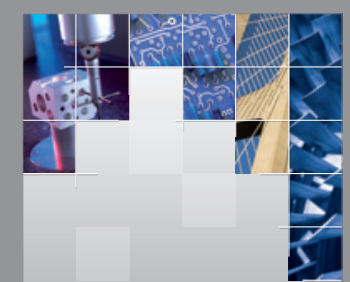

\section{Enfincering}
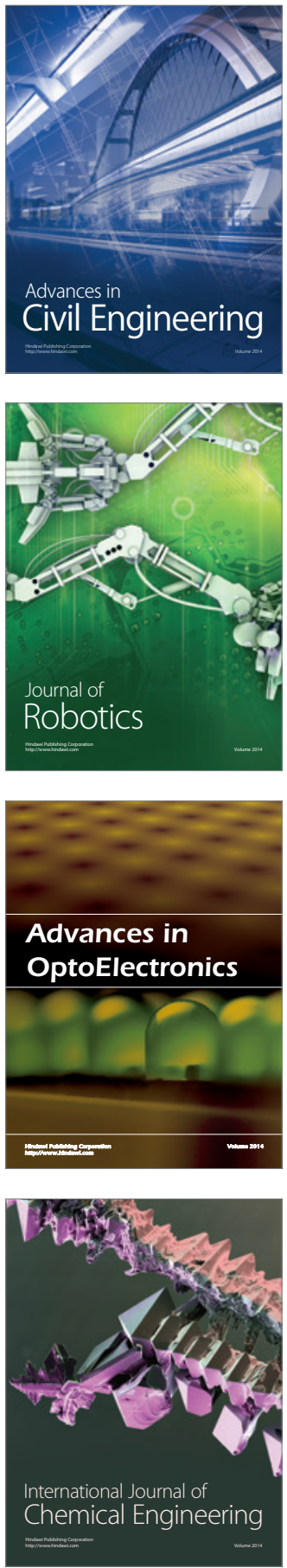

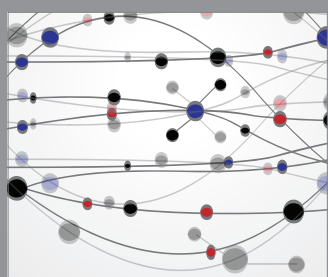

The Scientific World Journal

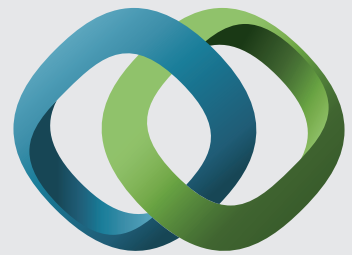

\section{Hindawi}

Submit your manuscripts at

http://www.hindawi.com
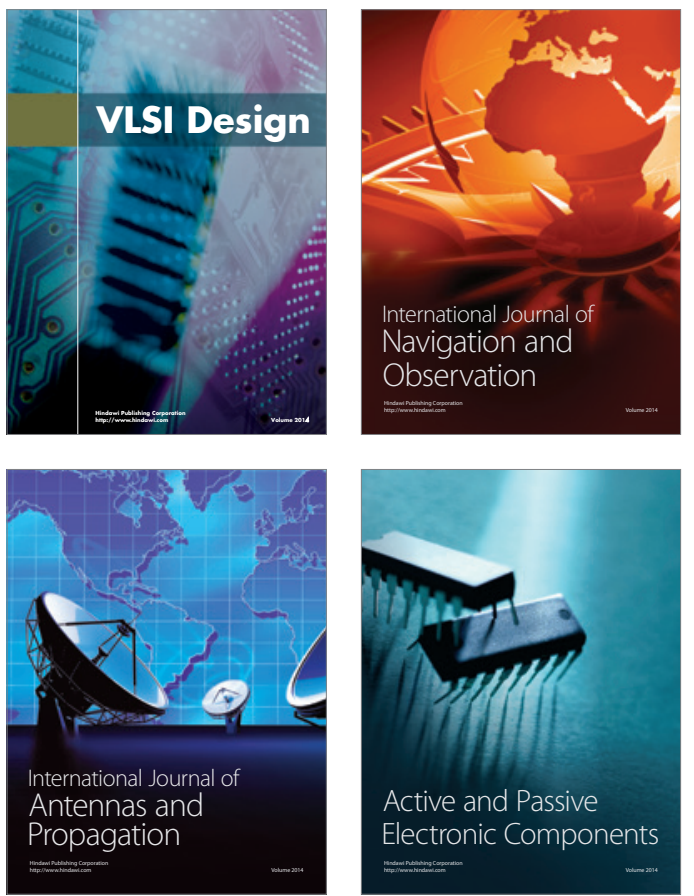
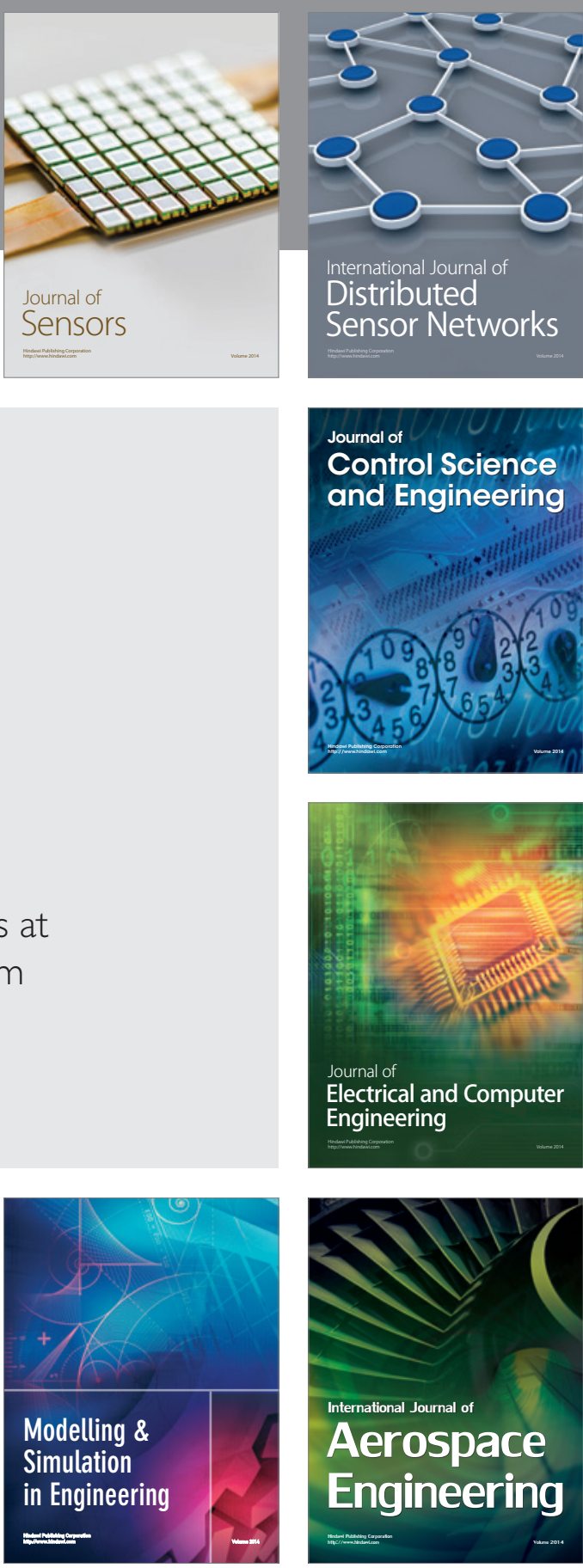

International Journal of

Distributed

Sensor Networks

Journal of

Control Science

and Engineering
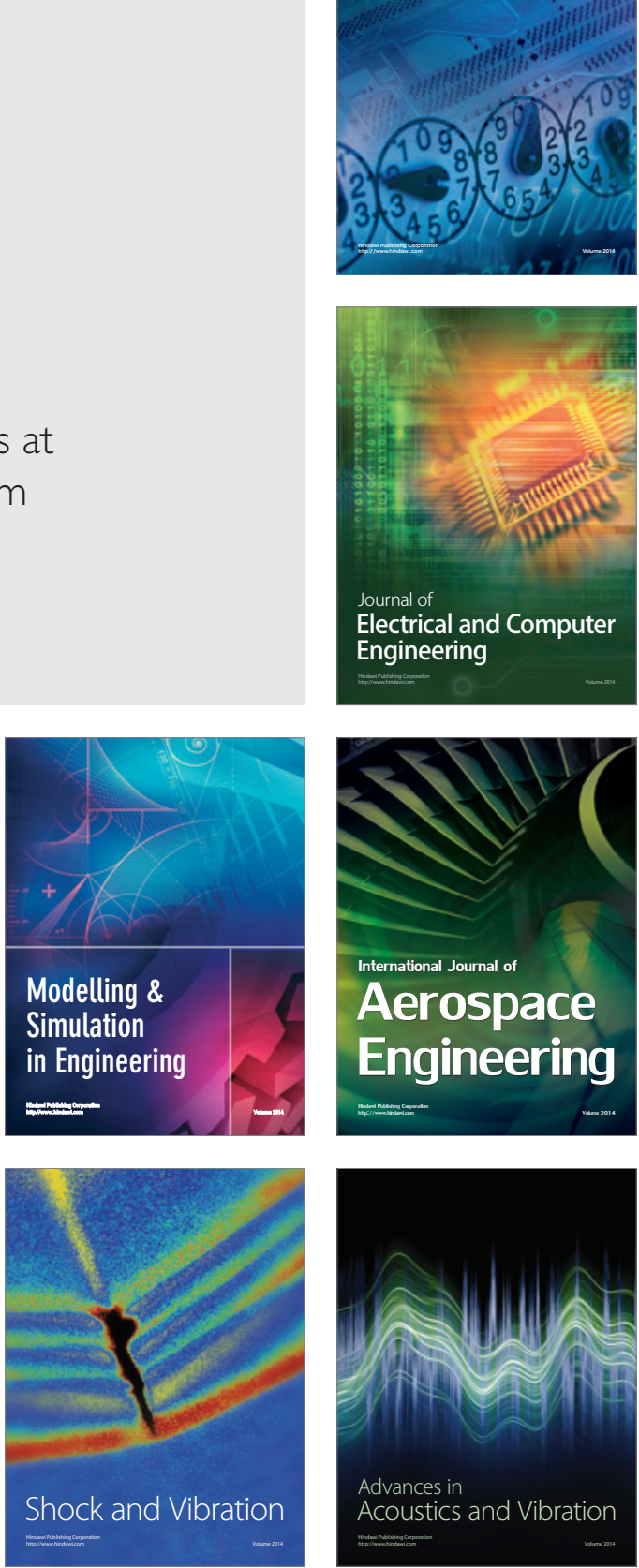